\title{
Colony aggression: Effects of benzodiazepines on intruder behavior
}

\author{
SANDRA E. FILE \\ The School of Pharmacy, University of London, London, England
}

\begin{abstract}
Two colonies of 12 male hooded rats were established for several months. Intruder rats were introduced into the colony, and agonistic encounters were observed for $18 \mathrm{~min}$. Acute administration of chlordiazepoxide $(5 \mathrm{mg} / \mathrm{kg})$ and lorazepam $(.25 \mathrm{mg} / \mathrm{kg})$ to intruder rats had little effect on aggressive behavior. After 5 days of benzodiazepine administration to the intruders, there were fewer fights and less time was spent fighting. The residents directed fewer bites and aggressive behaviors toward the intruders. The intruders submitted less and initiated more interaction (both sniffing and agonistic behaviors) with the residents.
\end{abstract}

Benzodiazepines are reported to have a taming effect on vicious cynomolgus monkeys and wild zoo animals (Heuschele, 1961; Randall, Schallek, Heise, Keith, \& Bagdon, 1960) and to decrease aggression in several laboratory test situations (Bauen \& Possanza, 1970; Christmas \& Maxwell, 1970; Cole \& Wolf, 1966; Malick, Sofia, \& Goldberg, 1969). However, high doses caused ataxia, muscle relaxation, or sedation (Delini-Stula \& Vassout, 1979; Essman, 1978; K. A. Miczek \& Krsiak, 1979).

In low doses, acute administration of diazepam and chlordiazepoxide reduces shock-elicited fighting in mice (Sofia, 1969), but is generally without effect on isolation-induced aggression (J. A. Miczek \& O'Donell, 1980; Sofia, 1969; Valzelli, 1973). In monkeys, low doses of benzodiazepines reduce attacks of intruders (Delgado, 1973), but have a biphasic effect on aggressive acts by a dominant monkey toward others in a group, first increasing and then decreasing aggression (Apfelbach \& Delgado, 1974). In general, chronic treatment with benzodiazepines enhances fighting in mice (Fox, Tuckosh, \& Wilcox, 1970; Fox, Webster, \& Guerriero, 1972; Guaitani, Marcucci, \& Garattini, 1971), although this has not been universally found (Malick, 1978).

To date, the reports of increased aggression have been in intraspecies fighting in grouped animals, have been limited to low doses, and, in the majority of cases, have followed chronic treatment of mice. The purpose of this study was, therefore, to compare the effects of acute and chronic ( 5 days) administration of low doses of two benzodiazepines on intra-

I am grateful to Peter Mabbut for expert technical assistance and to Roche Products and Wyeth for the gifts of chlordiazepoxide and lorazepam. This work was supported by a medical research council project grant to S.E.F., who is a Wellcome Trust Senior Lecturer. The author's mailing address is: Department of Pharmacology, The School of Pharmacy, University of London, Brunswick Square, London WC1N 1AX, England. species aggression in rats. The doses of chlordiazepoxide and lorazepam were selected because they were the lowest that caused sedation after acute administration and had an anxiolytic effect after chronic administration (File, 1980; File \& Hyde, 1978). With these doses, there are no differences between the plasma concentrations of the parent compounds or their metabolites for acute and for chronic administration (File, 1983).

Intruder-elicited attack was chosen as the means for generating intraspecies aggression in rats because it permits changes in attack, defense, and social investigatory behaviors to be recorded. Distinct categories of attack and defense behavior have been described (Blanchard, Blanchard, Takahashi, \& Kelley, 1977), and illustrations of these postures can be found in Silverman (1979).

\section{METHOD}

\section{Rat Colony}

Two colonies of 12 male hooded Lister rats were established for a period of 12-18 months. The rats had food and water available ad lib and were housed in a three-story enclosure (each floor was $91 \times 60 \mathrm{~cm}$; the top story was $15 \mathrm{~cm}$ high, and the other two were $20.5 \mathrm{~cm}$ high) (see Figure 1). The rats weighed approximately $350 \mathrm{~g}$ when the colonies were established. Conflict between the residents continued throughout the entire period, and bites were inflicted periodically. These were all on the rats' dorsal surfaces, and the most frequent damage was to tails. Fights frequently broke out among the residents after a period of intruders' being in the colony, even though the participants had not necessarily interacted with the intruder.

In neither colony did the dominant male (judged by successful encounters among the residents and by competition for food and water) attack the intruder rats. The third-ranking male, sometimes helped by two others, reliably attacked all intruders. About half the residents did not interact with the intruders in any way, even when an intruder walked over them. For group-housed intruders, the mean latency for the first interaction with the residents was $21.7 \pm 2.76 \mathrm{sec}$, the first agonistic encounter occurred after $54.9 \pm 12.61 \mathrm{sec}$, and the first fight occurred after 158.3 $\pm 42.21 \mathrm{sec}$. The distribution of agonistic encounters was studied over a period of $30 \mathrm{~min}$, and on the basis of the results, an observation period of $18 \mathrm{~min}$ was selected for the drug study. 


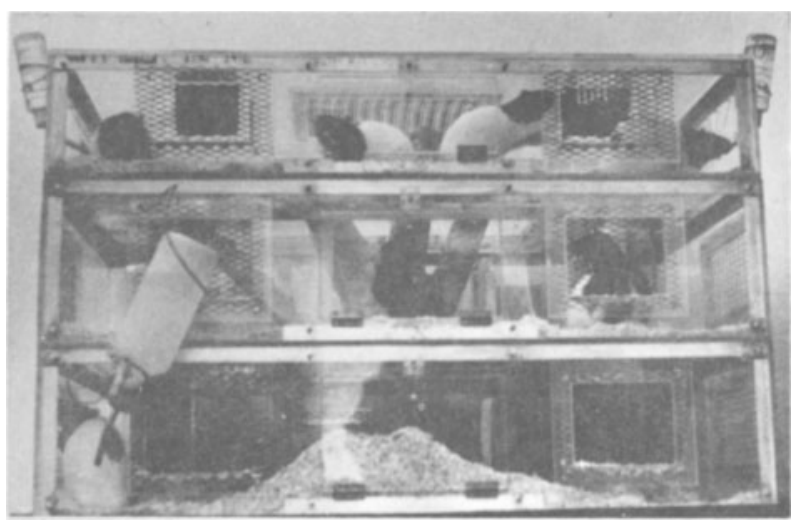

Figure 1. Three-story long-established colony of 12 male rats.

\section{Drugs}

Chlordiazepoxide hydrochloride (CDP-Roche Products Ltd.) was dissolved in deionized water to a concentration of $2.5 \mathrm{mg} / \mathrm{ml}$. Lorazepam injection (LOR-Wyeth) was further diluted with water to a concentration of $.125 \mathrm{mg} / \mathrm{ml}$. Control rats received injections of water or vehicle. All injections were given intraperitoneally $30 \mathrm{~min}$ before testing.

\section{Procedure}

Group-housed male intruder rats (approximately $250 \mathrm{~g}$ ) were placed singly in the middle floor of the colony, and the resulting interactions with the resident rats were scored for $18 \mathrm{~min}$. The frequencies of the following behaviors were recorded: fighting, boxing, other aggressive acts (kicking, pushing, jumping on, and standing on the other rat), biting, grooming, and displacement behaviors (self-grooming, eating, and drinking).

The following independent groups ( $n=6$ per group) of male intruders were tested: control (water or vehicle), CDP $(5 \mathrm{mg} / \mathrm{kg}-$ acute or after 5 days of daily injections), and LOR $(.25 \mathrm{mg} / \mathrm{kg}-$ acute or after 5 days of daily injections). All the rats received equal amounts of handling before their tests. The rats were tested over a period of 3 weeks in an order randomized for drug treatment.

\section{Statistics}

The data for the time spent fighting and the number of fights were analyzed by two-way analyses of variance, with treatment (acute or chronic) and drug (control, CDP, or LOR) as the two factors. Comparisons between the control group and the individual treatment groups were then made with Dunnett's multiple range test. Analyses of variance were also run on three combined categories: (1) all aggressive acts by residents; (2) social investigation (sniff and groom) by residents; (3) social investigation by intruders. When a factor reached overall significance on this analysis, the individual treatments were then compared with the controls for each individual behavior using MannWhitney $U$ tests. Comparisons between the control and the drug groups for the number of submissions and the incidence of displacement behaviors were made with Mann-Whitney $U$ tests.

\section{RESULTS}

Table 1 shows the mean scores for the control and drugged intruder rats. Benzodiazepine treatment had a significant effect on the time spent fighting and on the number of fights that occurred $[\mathrm{Fs}(2,30)=9.2$ and 13.0, ps $<.001$ ], and the difference between acute and chronic treatment was also significant $[\mathrm{Fs}(1,30)$ $=12.2$ and 29.5 , ps $<.002$ and .001 , respectively]. For both measures, there was a treatment $x$ drug interaction $[\mathrm{Fs}(2,30)=4.5$ and 8.0 , ps $<.02$ and .002 , respectively]. Dunnett's tests confirmed that, with chronic treatment, both CDP and LOR significantly reduced both the time spent fighting and the number of fights, whereas after acute administration, only CDP significantly reduced the time spent fighting; the number of fights was reduced by acute CDP but increased by acute LOR.

Chronic (5 days) treatment with benzodiazepines also resulted in a significant reduction in the number of times the intruder submitted (by lying on the back). The intruders were subjected to less aggression when

Table 1

Mean Time Spent Fighting (in Seconds) and Mean Frequency of Occurrence of Various Behaviors During an 18-Min Test

\begin{tabular}{|c|c|c|c|c|c|}
\hline & \multirow[b]{2}{*}{$\begin{array}{l}\text { Control } \\
(\mathrm{n}=12)\end{array}$} & \multicolumn{2}{|c|}{ CDP } & \multicolumn{2}{|c|}{ LOR } \\
\hline & & $\begin{array}{l}\text { Acute } \\
(n=6)\end{array}$ & $\begin{array}{l}5 \text { Days } \\
(n=6)\end{array}$ & $\begin{array}{c}\text { Acute } \\
(n=6)\end{array}$ & $\begin{array}{l}5 \text { Days } \\
(n=6)\end{array}$ \\
\hline Intruder Self-Grooms/Eats & .8 & .7 & $2.3 * *$ & 1.3 & $3.7^{*}$ \\
\hline Intruder Sniffs Resident & 1.5 & 3.6 & $10.0 * *$ & 2.1 & $3.8^{*}$ \\
\hline Resident Sniffs Intruder & 9.5 & 4.5 & 5.2 & 4.5 & 3.8 \\
\hline Intruder Grooms & .0 & .2 & .5 & .0 & 1.3 \\
\hline Resident Grooms & .5 & 2.0 & .7 & .8 & 3.5 \\
\hline Aggression by Intruder & .0 & .0 & $.8^{*}$ & .0 & $.8^{*}$ \\
\hline Aggression by Resident & 1.2 & 1.3 & $.7 *$ & .9 & $.5^{*}$ \\
\hline Intruder Submits & 3.3 & 3.0 & $.0 * *$ & 2.5 & $.2 * *$ \\
\hline Resident Submits & .0 & .3 & .3 & .3 & .8 \\
\hline Resident Bites & 1.3 & .8 & $.2 *$ & .5 & $.2 *$ \\
\hline Number of Fights & 7.5 & 4.5 & $.3 \dagger$ & 11.6 & $2.3 \dagger$ \\
\hline Time Spent Fighting & 40.6 & 19.3 & $1.2 \dagger$ & 48.8 & $6.3 \dagger$ \\
\hline
\end{tabular}

Note-The intruders were placed in the colony 30 min after injection of vehicle, chlordiazepoxide (CDP; $5 \mathrm{mg} / \mathrm{kg}$ ) or lorazepam (LOR; .25 mg/kg). $\quad{ }^{*} p<.05$, Mann-Whitney U test (two-tailed). $\quad{ }^{* *} p<.01$, Mann-Whitney U test (two-tailed). $\quad$ tSignificantly different from controls by analysis of variance (see text for details). 
they were chronically treated with benzodiazepines $[F(1,30)=5.36, p<.05]$; this was reflected in both the number of bites received and in the incidence of minor agonistic acts. This treatment also resulted in the intruders' initiating significantly more social interactions with the residents $[F(1,30)=7.6, p<.05]$. This was due to a significant increase in the incidence of sniffing the residents. The intruders also showed significantly more aggressive behaviors (kicking, pushing, jumping on) toward the residents and an enhanced incidence of self-grooming after benzodiazepine treatment.

\section{DISCUSSION}

These experiments demonstrate that it is possible reliably to obtain attacks on intruder rats placed in a well-established colony of male hooded rats. The first agonistic encounter occurred, on average, within the first minute, and an observation period of 618 min was sufficient to score agonistic encounters. In this respect, our colonies differed from those used by Flanelly and Lore (1975), in which fighting did not occur until $1 \mathrm{~h}$ after the introduction of an intruder. Both the maturity of the colony (several months) and previous experience with intruders are likely contributory factors to our short attack latency (Blanchard, Takahashi, \& Blanchard, 1977). The attack and defensive postures displayed in the present experiments were identical to those observed in hooded rats housed singly for 5-10 days and then faced with intruders in their home cages (File \& Deakin, 1980; File, Deakin, Longden, \& Crow, 1979; File, Hyde, \& MacLeod, 1979; File, James, \& MacLeod, 1981).

All the bites on intruders were inflicted by one resident in each colony, and, on the basis of this measure, such a male is usually designated the alpha, or dominant, male (Blanchard, Fukunaga, Blanchard, \& Kelley, 1975). However, in our two colonies, the male that attacked intruders was not the dominant male in fights among the residents and did not become the dominant male after experience with intruder attack.

There was no evidence of increased aggression following acute treatment of the intruders with low doses of chlordiazepoxide or lorazepam. In general, following chronic treatment there was a reduction in aggression, as evidenced by less fighting and by fewer bites and aggressive acts directed at the intruder. This change was not the result of the drugtreated intruders' becoming more submissive. Rather, they submitted less often to the residents and initiated more interaction with them, both social investigatory and agonistic in nature. Increased social interaction following 5 days of benzodiazepine treatment has also been found in pairs of rats observed in arenas unfamiliar to them, in which neither had established territory; under such test conditions, acute administration of benzodiazepines has led to less social interaction and reduced motor activity (File, 1979; File \& Hyde, 1978).

The results of this experiment suggest that the benzodiazepines changed the intruders' behavior in such a way as to inhibit attacks from the residents. An increased incidence of the intruders' initiating interactions, and their failure to adopt defensive postures or to run away, are likely to have been contributory factors.

\section{REFERENCES}

Apfelbach, R., \& Delgado, J. M. R. Social hierarchy in monkeys (Macaca mulatta) modified by chlordiazepoxide hydrochloride. Neuropharmacology, 1974, 13, 11-20.

Bauen, A., \& Possanza, G. J. The mink as a psychopharmacological model. Archives Internationales Pharmacodynamic, 1970, 186, 133-136.

Blanchard, R. J., Blanchard, D. C., Takahashi, T., \& Kelley, J. R. Attack and defensive behaviour in the albino rat. Animal Behaviour, 1977, 25, 622-634.

Blanchard, R. J., Fukunaga, K. K., Blanchard, D. C., \& Kelley, M. J. Conspecific aggression in the laboratory rat. Journal of Comparative and Physiological Psychology, 1975, 89, 1204-1209.

Blanchard, R. J., Takahashi, L. K., \& Blanchard, D. C. The development of intruder attack in colonies of laboratory rats. Animal Learning \& Behavior, 1977, 5, 365-369.

Christmas, A. J., \& Maxwell, D. R. A comparison of the effects of some benzodiazepines and other drugs on aggressive and exploratory behaviour in mice and rats. Neuropharmacology, 1970, 9, 17-29.

Cole, H. F., \& Wolf, H. H. The effects of some psychotropic drugs on conditioned avoidance and aggressive behaviors. Psychopharmacologia, 1966, 8, 389.

Delgado, J. M. R. Antiaggressive effects of chlordiazepoxide. In S. Garattini, E. Mussini, \& L. O. Randall (Eds.), The benzodiazepines. New York: Raven Press, 1973.

Delini-Stula, A., \& Vassout, A. Differential effects of psychoactive drugs on aggressive responses in mice and rats. In $\mathbf{M}$. Sandler (Ed.), Benzodiazepines and aggression. New York: Raven Press, 1979.

Essman, W. B. Benzodiazepines and aggressive behavior. In L. Valzelli (Ed.), Psychopharmacology of aggression. Basel: Karger, 1978.

File, S. E. ACTH as a mediator in anxiety. In B. Saletu, P. Berner, \& L. Hollister (Eds.), Neuropsychopharmacology. Oxford and New York: Pergamon Press, 1979.

File, S. E. The use of social interaction as a method for detecting anxiolytic activity of chlordiazepoxide-like drugs. Journal of Neuroscience Methods, 1980, 2, 219-238.

File, S. E. Behavioral pharmacology of benzodiazepines. Progress in Neuro-psychopharmacology, 1983, in press. (Paper read to CINP meeting, Hong Kong, October 1981).

File, S. E., \& Deakin, J. F. W. Chemical lesions of both dorsal and median raphe nuclei and changes in social and aggressive behavior in rats. Pharmacology, Biochemistry and Behavior, 1980, 12, 855-859. 
File, S. E., Deakin, J. F. W., Longden, A., \& Crow, T. J. An investigation of the role of the locus coeruleus in anxiety and agonistic behaviour. Brain Research, 1979, 169, 411-420.

File, S. E., \& Hyde, J. R. G. Can social interaction be used to measure anxiety? British Journal of Pharmacology, 1978, 62, 19-24.

File, S. E., Hyde, J. R. G., \& MacLeod, N. K. 5,7-dihydroxytryptamine lesions of dorsal and median raphe nuclei and performance in the social interaction test of anxiety and in a homecage aggression test. Journal of Affective Disorders, 1979, 1, 115-122.

File, S. E., James, T. A., \& MacLeod, N. K. Depletion in amygdaloid 5-hydroxytryptamine concentration and changes in social and aggressive behaviour. Journal of Neural Transmission, 1981, 50, 1-12.

Flanelly, K., \& LoRe, R. Dominance-subordination in cohabiting pairs of adult rats: Effects on aggressive behavior. $\mathbf{A g}$ gressive Behavior, 1975, 1, 331-340.

Fox, K. A., Tuckosh, J. R., \& Wilcox, A. H. Increased aggression among grouped male mice fed chlordiazepoxide. European Journal of Pharmacology, 1970, 11, 119-121.

Fox, K. A., Webster, J. C., \& Guerriero, F. J. Increased aggression among grouped male mice fed nitrazepam and flurazepam. Pharmacological Research Communications, 1972, 4, 157-162.

Guaitani, A., Marcucci, F., \& Garattini, S. Increased aggression and toxicity in grouped male mice treated with tranquilizing benzodiazepines. Psychopharmacologia, 1971, 19, 241-245.

Heuschele, W. P. Chlordiazepoxide for calming 200 animals. Journal of the American Veterinary Medical Association, 1961, 139, 996-998.
Malick, J. B. Selective antagonism of isolation-induced aggression in mice by diazepam following chronic administration. Pharmacology, Biochemistry and Behavior, 1978, 8, 497-499.

Malick, J. B., SofiA, R. D., \& Goldberg, M. E. A comparative study of the effects of selected psychoactive agents upon three lesion-induced models of aggression in the rat. Archives Internationales Pharmacodynamic, 1969, 181, 459-465.

MiczeK, J. A., \& O'Donell, J. M. Alcohol and chlordiazepoxide increase suppressed aggression in mice. Psychopharmacologia, 1980, 69, 39-44.

MiczeK, K. A., \& Krsiak, M. Drug effects on agonistic behavior. In T. Thompson \& P. Dews (Eds.), Advances in behavioral pharmacology (Vol. 2). New York: Academic Press, 1979.

Randall, L. O., Schallek, W., Heise, G. A., Keith, E. F., \& BAGDon, R. E. The psychosedative properties of methaminodiazepoxide. Journal of Pharmacology \& Experimental Therapeutics, 1960, 129, 163-171.

Silverman, A. P. Aggression in a social context: What can drugs do? In M. Sandler (Ed.), Benzodiazepines and aggression. New York: Raven Press, 1979.

SoriA, R. D. Effects of centrally active drugs on four models of experimentally-induced aggression in rodents. Life Sciences, $1969,8,705-716$.

Valzell, L. Activity of benzodiazepines on aggressive behavior in rats and mice. In S. Garattini, E. Mussini, \& L. O. Randall (Eds.), The benzodiazepines. New York: Raven Press, 1973.

(Manuscript received July 7, 1981; revision accepted for publication February 8, 1982.) 